\title{
Choroidal and Ciliary Body Melanoma pT1 TNM Finding v8
}

National Cancer Institute

\section{Source}

National Cancer Institute. Choroidal and Ciliary Body Melanoma pT1 TNM Finding v8. NCI Thesaurus. Code C140631.

Choroidal and ciliary body melanoma, tumor size category 1. (from AJCC 8th Ed.) 